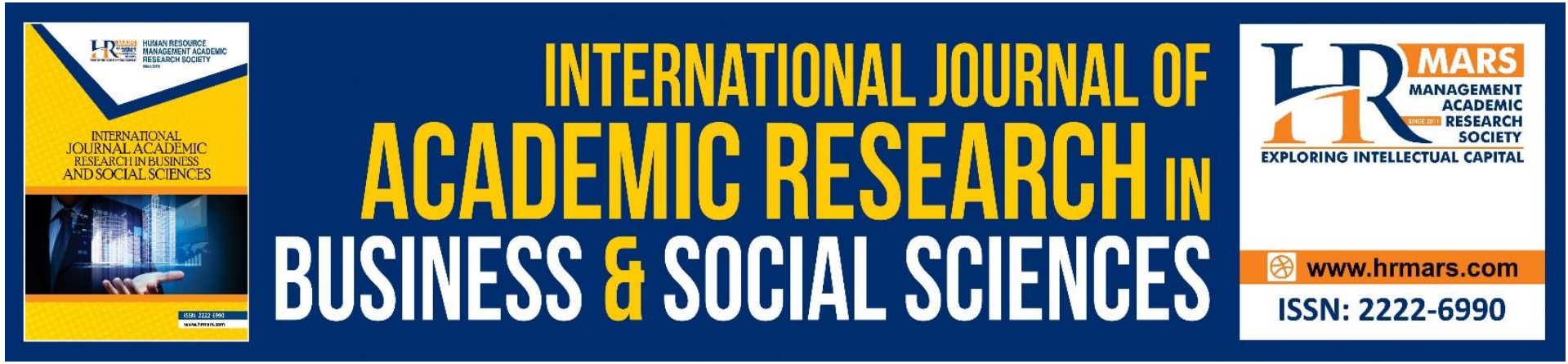

\title{
The Influences of Work-Related Stress in Determining Work Performance Among Language Lecturers' in Public Universities
}

Nurul Asma Mazlan, Suhaila Zailani@ Ahmad, Zamri Arifin, Nur Aqilah Norwahi, Mohd Faizulamri Mohd Saad

To Link this Article: http://dx.doi.org/10.6007/IJARBSS/v11-i8/10814 DOI:10.6007/IJARBSS/v11-i8/10814

Received: 03 June 2021, Revised: 28 June 2021, Accepted: 20 July 2021

Published Online: 11 August 2021

In-Text Citation: (Mazlan et al., 2021)

To Cite this Article: Mazlan, N. A., Ahmad, S. Z., Arifin, Z., Norwahi, N. A., \& Saad, M. F. M. (2021). The Influences of Work-Related Stress in Determining Work Performance Among Language Lecturers' in Public Universities. International Journal of Academic Research in Business and Social Sciences, 11(8), 1161-1168.

Copyright: @ 2021 The Author(s)

Published by Human Resource Management Academic Research Society (www.hrmars.com)

This article is published under the Creative Commons Attribution (CC BY 4.0) license. Anyone may reproduce, distribute, translate and create derivative works of this article (for both commercial and non-commercial purposes), subject to full attribution to the original publication and authors. The full terms of this license may be seen at: http://creativecommons.org/licences/by/4.0/legalcode

Vol. 11, No. 8, 2021, Pg. 1161 - 1168

Full Terms \& Conditions of access and use can be found at http://hrmars.com/index.php/pages/detail/publication-ethics 


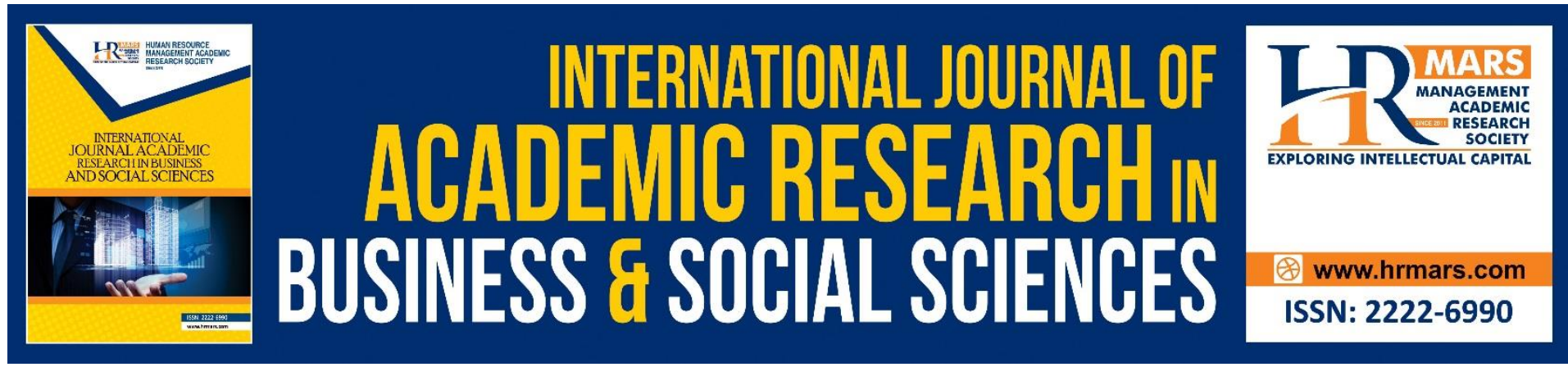

\title{
The Influences of Work-Related Stress in Determining Work Performance Among Language Lecturers' in Public Universities
}

\author{
Nurul Asma Mazlan \\ Academy of Language Studies, University Teknologi MARA Melaka, Malaysia
}

Suhaila Zailani@ Ahmad, Zamri Arifin

Faculty of Islamic Studies, University Kebangsaan Malaysia, Malaysia

\author{
Nur Aqilah Norwahi \\ Academy of Language Studies, University Teknologi MARA Melaka, Malaysia
}

\section{Mohd Faizulamri Mohd Saad}

Faculty of Islamic Studies, University Kebangsaan Malaysia, Malaysia

\begin{abstract}
Lecturers' increased workload is an issue that has not been widely discussed even though it has emotionally affected the lecturers and eventually influences their work productivity. Therefore, this study is conducted to identify the factors that lead to poor work performance among 113 language lecturers in three Malaysian public universities through a random sampling Likert scale survey. From literature review, it has been found that there is significant positive relationship between all variables (heavy and increased workload, grade promotion, additional working hours and large group of students per lecturer in a classroom) and lecturers' work performance.
\end{abstract}

Keywords: Workload, Work Performance, Stress, Language Lecturer.

\section{Introduction}

The increasing workload assigned to lecturers has been rather a controversial issue as they are expected to do more than teaching and supervising the students but at the same time to also participate in seminars, workshops and community service as well as research workload. Needless to say, these are the requirements for grade promotion in the tertiary institutions. Lecturers do not only need to prepare for pedagogy and methodology but the lecturing process also includes examining student's performance and supervision of projects carried out by students (Philips \& Okonmah, 2020). An article that went viral on social media in 2020, "Bahagiakah Seorang Pensyarah? (Is being a lecturer fulfilling?)", written by a lecturer from the Research Centre for Dakwah and Leadership, National University of Malaysia, emphasised on the challenges that lecturers in both public and private tertiary institutions are facing 
nowadays. In this article, Associate Professor Dr. Salasiah Hanin Hamjah stated that current lecturers are hampered with increased workload and wider job scopes in order to receive a grade promotion. Due to these demands, the lecturers are finding it more difficult to focus on the main task which is the teaching process and eventually may affect their teaching and students' learning quality. Hence, this study investigates the factors that influence lecturers' work performance in order to attain a high educational impact on the stakeholders (Azman et. al., 2016).

\section{Literature Review}

In any tertiary institutions, lecturers are often entrusted with tasks that become a factor in their work performance appraisal. Certainly, fulfilling the assigned workload is a criterion for work performance appraisal (Hasibuan, 1990). According to Cherniss and Goleman (2001), individual work performance has been proven to improve group performance and ultimately the efficacy of the organization. In addition, it is also found that work performance significantly influence the results or success of an organization (Benjamin \& Olajumoke, 2013). Thus, work performance is described by the quality and productivity of work and lecturers who have a laden of workload may feel burdensome as they often need to complete the tasks after office hours. An individual's contentment is measured not by the material needs but is based on positive emotions, involvement in teaching activities, social interactions and real life meaning (Awang \& Ahmad, 2010).

The challenges experienced by lecturers nowadays include equipping themselves with information and communication technological skills, soft skills, effective university management skills and at the same time to become the beacon of hope to uplift the society. In the past, lecturers focused mainly on teaching and supervising students and being involved in community service, but now the scope of work of lecturers is augmented by their involvement in research. Moreover, the challenge in attaining grade promotion is another factor that influence lecturers' credibility when carrying out these assigned tasks (Mahmood, 2018). In order to reach the annual Key Performance Indicator (KPI) established by the universities (Omar \& Azim, 2019), lecturers are also required to produce research articles to be published in SCOPUS/WOS/ERA/MyCite journals. This requirement demands a variety of multitasking skills and has overwhelmed the lecturers. In a nutshell, lecturers are burdened with increasingly challenging tasks in this generation (Hamjah, 2020).

According to Rahim (2000), the dissatisfaction among lecturers exists due to the increased workload and a myriad of expectations. Since teaching performance and workload are interrelated (Azman et al., 2016), from an ergonomic perspective, each workload received by a person must be appropriate and in line with their physical and cognitive abilities and limits (Pracinasari, 2013). On the other hand, Chaudhry et al (2011) stated that there is a positive relationship between the workload of a lecturer with his work performance because it can improve the knowledge, skills and experience of lecturers, where indirectly can improve organizational performance. Nevertheless, Gahlann (2014); Rahim (2012); Zhou and George (2001) have rejected this notion. They pointed out that there is no positive relationship between excessive workload and work performance because such a situation will affect the emotions and motivation of lecturers, arise dissatisfaction with the organization and in turn impact on work productivity. 
In addition, lecturers are also burdened with co-curricular and student societies duties as advisors, examining assessments and evaluating student work, performing clerical duties, conducting college meetings and programs as well as handling non-professional duties. Lecturers are also expected to attend meetings, invigilate examinations, participate in various workshops and partake official duty in institutional activities such as convocations and community service have caused lecturers to experience emotional stress (Sarif et al., 2017). Should they fail in managing their stress, the relationship between the lecturers and their colleagues, organizations and students may be affected and consequently affect their teaching and learning quality too (Sipon, 2007). The decreased productivity of the teaching process due to emotional stress which has a significant impact on the performance and motivation of lecturers (Tambi \& Awang, 2019). This phenomenon has also prompted many lecturers to switch professions or opt for early retirement. According to Othman and Omar (2014), work pressure can lead to self-resentment over the work done and the avoidance and neglect of work which eventually form a desire to leave the profession. This situation indirectly affects the quality of education as well as the profession of lecturers, further hampering the endeavours to develop graduates who are capable in various fields.

Another element that contributes to work pressure is the insufficient time allotted for a task completion. This situation causes lecturers to feel distressed if the task outcome does not meet the expected quality due to short deadlines (Rahim, 2012; Othman, 2014). Any activities performed beyond anyone's ability will expedite a decline in work quality and productivity (Pracinasari, 2013; Markom et al., 2011) and in turn impact physical and mental health negatively. Hence, Nelms (1993), as cited by Othman and Omar (2014), suggests that lecturers' working hours should be only 35 hours weekly even if it is not enough to complete the assigned tasks. Lecturers should not be burdened with university-related tasks outside the working hours as they also need to spend quality time with family as well as performing personal needs.

Furthermore, the increasing number of students accepted to the higher learning institutions every year creates an imbalance between the number of lecturers and students (Yusof \& Sulaiman, 2012). A study by Collin and Parry-Johnes (2000) further explains that there is an imbalance between the number of lecturers and students in universities and this in turn increases the lecturers' workload and reduces their happiness level due to stress and increased working hour. The findings of this study are consistent with the study by Tambi \& Awang (2019) who found that the work stress factor dealing with students recorded the highest mean value which affected the emotional level of 108 lecturers and in turn affecting their work quality. Certainly the aspect of motivation should also be taken into account to avoid a decline in interest to remain working in the higher learning institutions.

All paragraphs must be indented.

\section{Conceptual Framework}

Figure 1 showed the conceptual framework for this study that illustrate the factors' of workrelated stress in determining lecturers' work performance. 


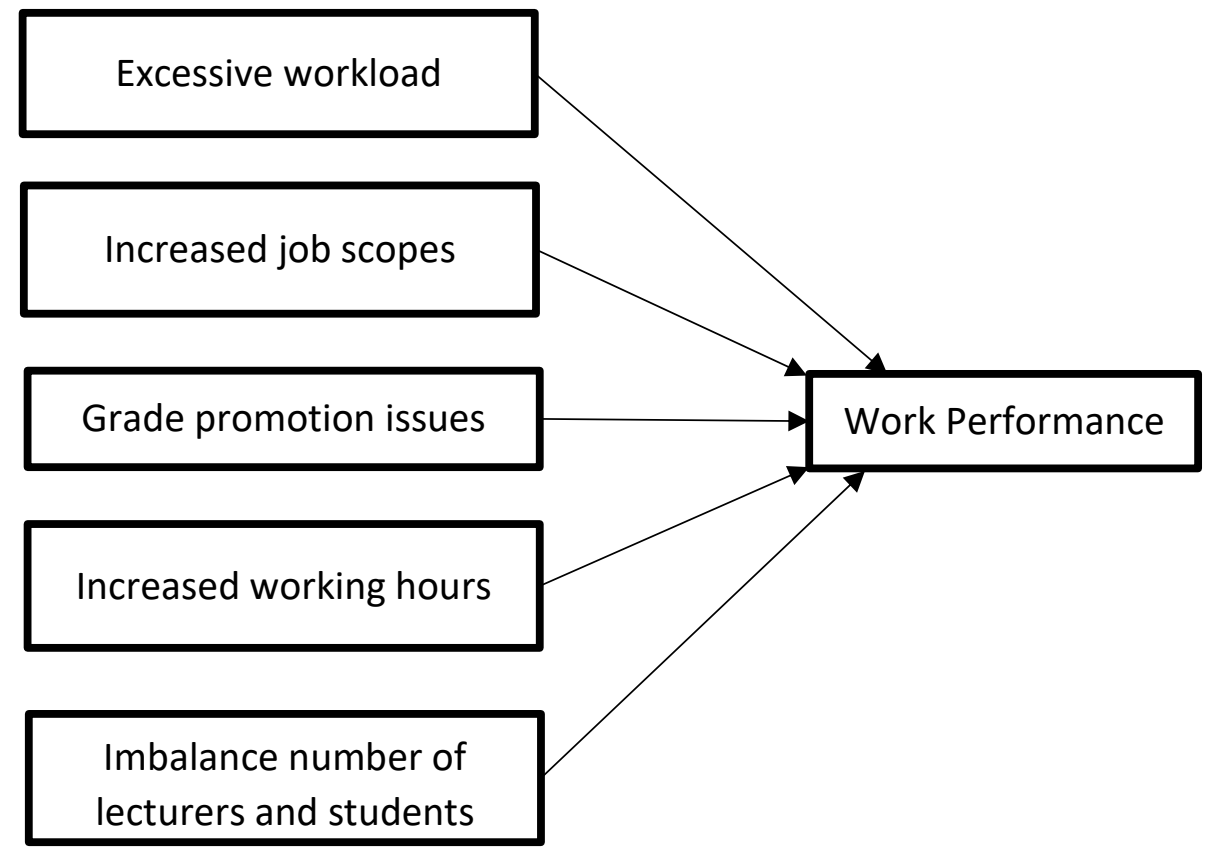

Figure 1. Conceptual Framework (source by author, 2021).

\section{Methodology}

This study adopts cross-sectional survey method on the sample from the entire population of language lecturers from Malaysian public universities to describe the opinions, behaviours and characteristics of the population subjects (Creswell, 2012). This survey method is chosen due to its suitability and accessibility for various topics and it provides specific explanation for the sample properties (Darusalam \& Husin 2018). The sampling method in this study uses simple random sampling and to determine the sample size, GPower Calculation 3.1 software is used to obtain the minimum sample size which is 107 . Since the actual sample of the study is 113 , then the minimum conditions of analysis are complied.

\section{Significance of the Study}

The findings of this study are expected to identify the factors that influence the decline in language lecturers' work performance. This study aims to provide positive and beneficial impacts not only to lecturers, as well as to prompt changes to be taken by the institutions while providing relevant ideas for researchers to do further research. The completion of this study can also assist the institutions to recognise the lecturers' emotional impact on their work performance. Besides that, the findings may also emphasise the importance of lecturers' well-being in increasing their work productivity which will benefit both the institutions and stakeholders.

Therefore, a further study should be conducted to investigate the motivational steps taken by the lecturers in overcoming excessive workload in higher learning institutions. Through similar research, it will also enable the lecturers to understand the shortcomings related to the job scope as well as the positive steps to enlighten the issues by reviewing their working strategies and capabilities. 


\section{Conclusion}

The policy of the Ministry of Higher Education emphasises on improving the quality of education, thus, the lecturers' duties are also increasing in line with the efforts to improve the performance of the higher learning institutions, especially in achieving international standards. Due to this reason, the lecturers must keep a stable level of motivation and emotional well-being as highly motivated lecturers are more enthusiastic and success driven in fulfilling their tasks (Carver, 2003). On the other hand, emotional stress causes lecturers to lose self-confidence and focus, become easily irritated and eventually making them less motivated to work (Jasmi et al., 2010). However, the globalisation era demands lecturers to move in sync in both self-development and professional development regardless the constant changes in the field of education. This situation indirectly drags lecturers with various challenging and heavy tasks which in turn causes them to be increasingly burdened with work (Rahim, 2012).

Thus, the element of motivation is needed to restore the lecturers' emotional stability and positive outlook towards this profession. Without motivation, lecturers find it difficult to achieve satisfaction in their careers and to meet the needs of the institutions in producing academics who are not only dedicated in teaching and learning activities but also innovative and active in research, and are able to compete internationally to elevate their knowledge in the academic field. Since there a lot of factors that hamper lecturers' work productivity, high motivational level can become a catalyst in self-development to realising the aspirations and ambitions within the lecturers.

\section{Acknowledgement}

The authors would like to express special gratitude to Academy of Language Studies, UiTM Melaka and Faculty of Islamic Studies, UKM giving trust to our team in conducting this study. The authors also would like to express their very great appreciation to anyone who involved directly or indirectly in this study and kept them motivated to complete this study successfully.

\section{Corresponding Author}

Nurul Asma binti Mazlan

Academy of Language Studies, Universiti Teknologi MARA, Melaka, Malaysia

Email: asmamazlan@uitm.edu.my

\section{References}

Azman, A. H., Mansor, N., Mohamad, Z. (2016). Impak Beban Kerja Terhadap Prestasi Kerja Pensyarah: Kes Kajian di Politeknik Sultan Mizan Zainal Abidin (PSMZA). E-Academia Journal UiTMT. 5(1), 1-11.

Awang, Z., \& Ahmad, J. H. (2010). Modelling Job Satisfaction and Work Commitment Among Lecturers: A Case of UiTM Kelantan. Proceedings of the Regional Conference on Statistical Sciences 2010 (RCSS'10), Jun, 241-255.

Benjamin, O., and Olajumoke, C. (2013). Influence of Mental Workload on Job Performance. International Journal of Humanities and Social Science, 3(15), 238-246.

Cherniss, C., \& Goleman, D., (2001). The Emotionally Intelligent Workplace. San Francisco: JosseyBass. 
Collins, S., \& Parry-Jones, B. (2000). Stress: The Perceptions of Social Work Lecturers in Britain. British Journal of Social Work, 30, 769-794.

Creswell, J. W. (2012). Educational Research: Planning, Conducting and Evaluating Quantitative and Qualitative Research. Edisi ke-4. Boston, MA: Pearson Education, Inc.

Chaudhry, A. A., Malik, M. I., Ahmad, I. (2011). Examining the Relationship of Work-Life Conflict and Employee Performance (A Case from NADRA Pakistan). International Journal of Business and Management. 6(10), 170-177.

Darusalam, G., \& Husin, S. (2018). Metodologi Penyelidikan dalam Pendidikan. $2^{\text {nd }}$ edition. Kuala Lumpur: Penerbit Universiti Malaya.

Gahlann V. S. (2014). The Effect of Role Overload and Role Ambiguity on Job Performance of IT Professionals in India. The IUP Journal of Management Research, 13(3), 37-49.

Hamjah, S. H. (2020). Bahagiakah Seorang Pensyarah? Disiarkan pada: 31 Ogos 2020. https://www.sinarharian.com.my [dirujuk pada 31 Ogos 2020].

Hasibuan, M. S. P. (1990). Manajemen Sumber Daya Manusia: Dasar Kunci Keberhasilan. Jakarta: CV Haji Mas Agung.

Jasmi, M. A., Zakaria, M. A., Saud, M. S. (2010). Lecturer Perceptions on Workload: The Impact towards the Effectiveness of the Teaching and Learning Process in Polytechnic. Kertas yang dibentang di International Conference on Technical and Vocational Education and Training, pada 10-11 Nov 2010. Bandung, Indonesia.

Mahmood, S. (2018). Permodelan Hubungan Faktor-Faktor Kerjaya Dengan Integrasi Ict Terhadap Amalan Pengajaran Berinovasi dalam Kalangan Guru Cemerlang. Tesis ljazah Doktor Falsafah. Universiti Sains Malaysia.

Markom, M., Abdul, N. A., Ariffin, A. K., Wahab, D. A., Husain, H., Ramli, N. F. L. (2011). Pengukuran Jam Notional Pensyarah dalam Meningkatkan Prestasi Ahli Akademik Universiti Penyelidikan. Seminar Education Engineering \& Built Environment (PeKA 2011). Kuala Lumpur: Universiti Kebangsaan Malaysia.

Nelms, B. F. (1993). The Arithmetics of Teacher Workloads. English Journal, 82(2), 92-93.

Noor, F. M. (2011). Faktor-Faktor Penentu Stres dalam Kalangan Guru-Guru: Kajian di Sekolah Rendah Mubaligh di Kuala Lumpur. Tesis sarjana. Kuala Lumpur: Open University Malaysia.

Othman, N. M. (2014). Pengaruh Tahap Stres terhadap Kepuasan Kerja dalam Kalangan Pengajar Kolej Vokasional di Negeri Pahang. Tesis sarjana Pendidikan. Univesiti Tun Hussein Onn Malaysia.

Othman, N., \& Omar, H. M. (2014). Beban Tugas dan Motivasi Pengajaran Guru di Sekolah Menengah Daerah Ranau. Journal for Educational Thinkers. 5, 35-57.

Omar, S., \& Azim, N. A. F. N. (2019). The Disposition of Motivational Strategies among English Language Teachers in Public Universities in Malaysia. Journal of ELT Research: The Academic Journal of Studies in English Language Teaching and Learning. 4(2), 140-151.

Philips, A. C., \& Okonmah, A. N. (2020). Lecturers' Workload and Productivity In Universities In Delta State. International Journal of Education, Learning and Development. 8(3), 111-136.

Pracinasari, I. (2013). Beban Kerja Fisik Vs Beban Kerja Mental. Surakarta: Universitas Sebelas Maret.

Rahim, A. (2000). Wawasan dan Agenda Pendidikan. Kuala Lumpur: Utusan Publications \& Distributors. [Dirujuk pada 20 September 2020].

Rahim, A. A. (2012). Beban Tugas Guru Sekolah Menengah di Daerah Batu Pahat, Johor Darul Takzim. Tesis Sarjana Pendidikan. Johor Darul Takzim: Universiti Teknologi Malaysia. 
Sarif, S. A., Mahmod, N. L., Kamaruddin, N. A. (2017). Kecenderungan Menjalankan Penyelidikan di Kalangan Pensyarah Kolej Komuniti Selandar, Melaka. e-Proceeding National Innovation and Invention Competition Through Exhibition (iCompEx'17). Pada 21-23 Mac 2017. Halaman 1-14.

Sipon, S. (2007). Pendidik Mesti Bijak Kawal Emosi. dalam Utusan Malaysia 27 Julai 2007. [Dirujuk pada 20 September 2020].

Tambi, N., \& Awang, S. Z. (2019). Hubungan antara Tekanan Kerja dan Kecerdasan Emosi terhadap Kepuasan Kerja dalam Kalangan Pensyarah Fakulti Sains Sosial dan Kemanusiaan, Universiti Kebangsaan Malaysia. Journal of Social Sciences and Humanities. 16(5): 1-19

Ujang, Z. (2012). Akademia Baru: Memartabat UTM Berjenama Global 2012- 2020. Johor: Penerbit UTM Press.

Yusof, S. M., \& Sulaiman, N. (2012). Analisis Kecekapan Staf Akademik Universiti Kebangsaan Malaysia. Prosiding Persidangan Kebangsaan Ekonomi Malaysia ke VII (PERKEM VII). Jilid 1: 337-347. Pada 4-6 Jun 2012. Ipoh, Perak.

Zhou, J., \& George, J. M. (2001). When Job Dissatisfaction Leads to Creativity: Encouraging The Expression Of Voice. Academy of Management Journal. 44, 682-696. 